\title{
Production and Use of the First-Row Transition Metal PET Radionuclides ${ }^{43,44} \mathrm{Sc},{ }^{52} \mathrm{Mn}$, and ${ }^{45} \mathrm{Ti}$
}

Ivis F. Chaple and Suzanne E. Lapi

Department of Radiology, University of Alabama at Birmingham, Birmingham, Alabama

\begin{abstract}
With the increasing focus on a more personalized approach to medicine using imaging techniques to select patients for targeted treatment or theranostic strategies, interest in the development of new radionuclides is expanding. Through the development of production and radiochemistry techniques, several new radiometals are being added to the toolbox of the nuclear imaging

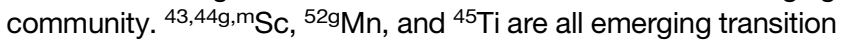
metal radionuclides and will be discussed in this short review. Each of these nuclides has unique imaging characteristics and shows promise for the development of new molecular imaging agents.
\end{abstract}

Key Words: scandium-43; scandium-44; manganese-52; titanium-45; isotope production; positron emission tomography

J Nucl Med 2018; 59:1655-1659

DOI: 10.2967/jnumed.118.213264

$\mathbf{T}$ he field of PET imaging has changed considerably in the last $5 \mathrm{y}$, shifting toward production and use of metal radionuclides in addition to continued research for ${ }^{18} \mathrm{~F}$ and ${ }^{11} \mathrm{C}$ compounds. Transition metal PET research is a rapidly growing area of interest. Specifically, this review will focus on work over the last $5 \mathrm{y}$ involving ${ }^{43,44 \mathrm{~g}, \mathrm{~m}} \mathrm{Sc},{ }^{52 \mathrm{~g}} \mathrm{Mn}$, and ${ }^{45} \mathrm{Ti}$.

Although scandium itself is not a true transition metal, its chemical properties are similar enough to that of transition metals to earn it the title of "transition metallike element." Because of the imaging and therapeutic characteristics of the scandium radionuclides ${ }^{43,44 \mathrm{~g}, \mathrm{~m} S \mathrm{Sc} \text { and }}{ }^{47} \mathrm{Sc}$, respectively, scandium is a potential candidate for the development of theranostic strategies that use complementary imaging and therapeutic compounds labeled with matching isotope pairs.

Interest in using manganese as a contrast agent for manganese-enhanced MRI has increased in recent years as an alternative to gadolinium-based contrast agents because of the toxicity issues of the latter (1). During the development of new agents for this technique, PET imaging with

Received Jul. 2, 2018; revision accepted Sep. 17, 2018.

For correspondence or reprints contact: Suzanne E. Lapi, University of Alabama at Birmingham, Wallace Tumor Institute 310F, 1824 6th Ave. S., Birmingham, AL 35233.

E-mail: lapi@uab.edu

Published online Sep. 27, 2018.

COPYRIGHT (c) 2018 by the Society of Nuclear Medicine and Molecular Imaging.
${ }^{52} \mathrm{Mn}$ can also help quantitatively determine the distribution, uptake, and excretory patterns of manganese-based MRI agents.

${ }^{45} \mathrm{Ti}$ is a promising candidate for radiolabeling peptides. Its half-life of $3.08 \mathrm{~h}$, although slightly shorter than that of the scandium radionuclides discussed, is longer than that of ${ }^{68} \mathrm{Ga}$, making it favorable for longer imaging times and centralized distribution. Additionally, its economical production makes implementation in many centers possible if chemistry challenges can be overcome.

\section{PRODUCTION OF ${ }^{43,44 G, M S C}$}

Recently, scandium nuclides have been of interest because of the potential therapeutic properties of ${ }^{47} \mathrm{Sc}$, which can be combined with ${ }^{43,44 \mathrm{~g}} \mathrm{Sc}$ for imaging. An excellent review article describes the production routes of these 3 scandium isotopes using proton beams, $\alpha$-particles, neutrons, and various target materials $(2) .{ }^{43} \mathrm{Sc}\left(\beta^{+}=88.1 \%\right.$, $\left.\mathrm{E}_{\beta+}=476 \mathrm{keV}\right)$ and ${ }^{44 \mathrm{~g}} \mathrm{Sc}\left(\beta^{+}=94.3 \%, \mathrm{E}_{\beta+}=632 \mathrm{keV}\right)$ have half-lives of 3.89 and $3.97 \mathrm{~h}$, respectively, (3). Although the 2 isotopes are similar, the main difference is the high-energy $\gamma$-ray $(1.157 \mathrm{MeV}$, emitted $99.9 \%$ of the time) associated with ${ }^{44 \mathrm{~g}} \mathrm{Sc}$. Additionally, ${ }^{44 \mathrm{~m}} \mathrm{Sc}$, which is coproduced with ${ }^{44 \mathrm{~g}} \mathrm{Sc}$, has a half-life of $58.6 \mathrm{~h}$ and has been suggested for use as an in vivo PET generator for ${ }^{44 g} \mathrm{Sc}(4)$. However, the longer half-life coupled with the high-energy $\gamma$-ray emitted from ${ }^{44 \mathrm{~g} S c}$, may lead to unfavorable dosimetry for shorter studies.

Production routes for ${ }^{43,44 \mathrm{~g}, \mathrm{~m}, 47} \mathrm{Sc}$ use either calcium or titanium targets, typically enriched for the desired isotope. ${ }^{43} \mathrm{Sc}$ can be produced via proton irradiation of ${ }^{43} \mathrm{Ca}$ or ${ }^{46} \mathrm{Ti}$, as well as $\alpha$-irradiation of ${ }^{40} \mathrm{Ca}$ or deuteron irradiation of ${ }^{44} \mathrm{Ca}(5-7) .{ }^{44 \mathrm{~g}, \mathrm{~m}} \mathrm{Sc}$ can be produced via proton irradiation of ${ }^{44} \mathrm{Ca},{ }^{47} \mathrm{Ti}$, or ${ }^{45} \mathrm{Sc}$ or deuteron irradiation of ${ }^{44} \mathrm{Ca}(2,4-$ $20)$. Enriched targets are preferred to avoid production of contaminants such as ${ }^{46,48} \mathrm{Sc}$ (18). Production studies of

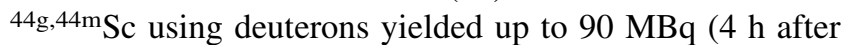
the end of bombardment) with a 3-h bombardment (21). In a similar study, ${ }^{44 \mathrm{~g}, 44 \mathrm{~m}} \mathrm{Sc}$ was produced via deuteron irradiation of enriched ${ }^{44} \mathrm{CaCO}_{3}$ targets, and the authors concluded that production of ${ }^{44 \mathrm{~g}, \mathrm{~m}} \mathrm{Sc}$ via calcium targets is preferable to ${ }^{43} \mathrm{Sc}$ because of the higher natural abundance of ${ }^{44} \mathrm{Ca}$ than of ${ }^{43} \mathrm{Ca}(7,22)$. Researchers have also studied the ${ }^{46} \mathrm{Ti}(\mathrm{p}, \alpha)^{43} \mathrm{Sc}$ reaction and showed that this pathway

$$
{ }^{43,44} \mathrm{Sc},{ }^{52} \mathrm{MN}, \text { AND }{ }^{45} \mathrm{Ti} \cdot \text { Chaple and Lapi }
$$


produced ${ }^{43} \mathrm{Sc}$ of higher radionuclidic purity than when using the ${ }^{43} \mathrm{Ca}(\mathrm{p}, \mathrm{n}){ }^{43} \mathrm{Sc}$ production route; however, the latter route produced ${ }^{43} \mathrm{Sc}$ in higher yields (18). Another source for ${ }^{44 \mathrm{~g}} \mathrm{Sc}$ is the ${ }^{44} \mathrm{Ti} /{ }^{44} \mathrm{Sc}$ generator $(8,23)$. Although the generator method has been investigated, only a small number of facilities in the world have these generators in use.

Purification of ${ }^{43} \mathrm{Sc}$ is detailed in a recent report that included various methods by several researchers (9). This article described separation methods summarized in Table 1 , all of which had favorable separation efficiency and recovery yields of more than $80 \%$ (9). Finally, another report detailed the separation of ${ }^{44 \mathrm{~g}} \mathrm{Sc}$, showing recovery of up to $80 \%$ using $\mathrm{H}_{2} \mathrm{O}$ as the final eluent on a UTEVA resin (Eichrom Technologies, LLC) (11). These methods for production and separation of ${ }^{43,44 \mathrm{~g}} \mathrm{Sc}$ enhance the availability of these nuclides for further development.

\section{RADIOCHEMISTRY AND IMAGING OF ${ }^{43,44}$ SC}

${ }^{43,44 \mathrm{~g}} \mathrm{Sc}$ has been proposed as a matched-pair theranostic radioisotope that is a longer-lived alternative to ${ }^{68} \mathrm{Ga}$ for imaging analogs of ${ }^{177} \mathrm{Lu}$. Scandium exists in the +3 oxidation state and is suitable for labeling of DOTA-derivatized biomolecules (24). In studies investigating ${ }^{44 \mathrm{~g}} \mathrm{Sc}$ as an imaging surrogate for ${ }^{177} \mathrm{Lu},{ }^{44 \mathrm{~g} S c}$-labeled cm09 (DOTAfolate conjugate) was determined to have comparable properties, with pharmacokinetics nearly identical to the same compound labeled with ${ }^{177} \mathrm{Lu}(25)$.

However, using 2 different elements may create problems if they show different biodistributions. Radioscandium allows for the development of true matched-pair theranostics using chemically identical constructs as opposed to chemically similar constructs. In this case, the pair would be ${ }^{43,44 \mathrm{~g} S c}$ as the diagnostic agent and ${ }^{47} \mathrm{Sc}$ as the therapeutic agent. Studies have compared the labeling efficiencies of ${ }^{68} \mathrm{Ga}$, ${ }^{177} \mathrm{Lu}$, and ${ }^{44 \mathrm{~g} S c}$ for DOTA-HPMA ( $N$-(2-hydroxypropyl) methacrylamide) conjugates and showed that the ${ }^{44 \mathrm{~g} S c-}$ labeled polymer was highly stable for up to $24 \mathrm{~h}$, showing promising characteristics for in vivo imaging (12). A similar study determined that reaction rates were increased when buffers including EtOH were used, allowing for lower temperatures and a reduced time to achieve labeling yields above $90 \%$ for DOTA complexes with these 3 radioisotopes $(26)$.

${ }^{44 \mathrm{~g}} \mathrm{Sc}$ was used to radiolabel DOTA-NAPamide for targeting of the melanocortin-1 receptor, with higher uptake in melanocortin-1 receptor-positive B16-F10 xenografts than in melanocortin-1 receptor-negative A375 xenografts (27). In another study, ${ }^{44 \mathrm{~g} S c-D O T A N O C}$ was synthesized with high radiochemical yields and used for dynamic PET imaging, showing continuous uptake and high-quality images in AR42J tumor xenografts, encouraging the transition into clinical applications (24). A similar study optimized radiolabeling conditions for peptides such as DOTANOC and NODAGANOC with ${ }^{44 \mathrm{~g} S c}$. After this, the authors determined that compounds labeled with ${ }^{44 \mathrm{~g}} \mathrm{Sc}$ had similar biodistribution to the same compounds labeled with ${ }^{68} \mathrm{Ga}$ except for a higher liver uptake seen in the latter (28). As these studies have indicated, ${ }^{43,44 \mathrm{~g}} \mathrm{Sc}$ shows promise for the development of matched-pair theranostic agents with ${ }^{47} \mathrm{Sc}$.

\section{PRODUCTION OF ${ }^{52}$ MN}

With a longer half-life of $5.6 \mathrm{~d}$, a $\beta^{+}$branching ratio of $29.4 \%$, and $\mathrm{E}_{\beta+}$ of $242 \mathrm{keV},{ }^{52 \mathrm{~g}} \mathrm{Mn}$ has characteristics complementary to the shorter-lived nuclides discussed and is a promising candidate for imaging of longer biologic processes or compounds that intrinsically contain manganese. However, ${ }^{52 \mathrm{~g}} \mathrm{Mn}$ emits multiple high-energy $\gamma$-rays, making work less favorable with ${ }^{52 \mathrm{~g}} \mathrm{Mn}$ than with some other radioisotopes (29). ${ }^{52 \mathrm{~g}} \mathrm{Mn}$ can be produced via the ${ }^{52} \mathrm{Cr}(\mathrm{p}, \mathrm{x})^{52 \mathrm{~g}} \mathrm{Mn}$ reaction, but radioisotope contaminants, including the long-lived ${ }^{54} \mathrm{Mn}$, can be produced via the ${ }^{54} \mathrm{Cr}(\mathrm{p}, \mathrm{n})$ reaction when natural chromium targets are used (27-29). Several groups have studied cross sections of these reactions to attain the highest yields with the fewest impurities $(30,31)$. Various natural chromium target configurations have been studied, including metal targets, electrodeposition, and pressed powder targets $(29,32,33)$. Targets have been irradiated with $16-\mathrm{MeV}$ protons or less, because of the desirable cross section

TABLE 1

${ }^{43} \mathrm{Sc}$ Production Routes Highlighted by Walczak et al. (9)

\begin{tabular}{|c|c|c|c|c|}
\hline Resin & Target dissolution & Target material eluent & ${ }^{43}$ Sc eluent & Reference \\
\hline $50 \mathrm{mg}$ of UTEVA resin & $1 \mathrm{~mL}$ of $9 \mathrm{M} \mathrm{HCl}$ & $5 \mathrm{~mL}$ of $9 \mathrm{M} \mathrm{HCl}$ & $400 \mu \mathrm{L}$ of $\mathrm{H}_{2} \mathrm{O}$ & (14) \\
\hline First, $70 \mathrm{mg}$ of DGA resin & $3 \mathrm{M} \mathrm{HCl}$ & $2-3 \mathrm{~mL}$ of $0.1 \mathrm{M} \mathrm{HCl}$ & $1 \mathrm{M}$ ammonium acetate, $\mathrm{pH} 4$ & (13) \\
\hline \multicolumn{5}{|l|}{$\begin{array}{l}\text { Second, } 100 \mathrm{mg} \text { of } \\
\text { Dowex }^{*} 50\end{array}$} \\
\hline $\begin{array}{l}\text { Chelex }{ }^{\dagger} 100 \text { bed size, } \\
0.8 \times 4.0 \mathrm{~cm}\end{array}$ & $1 \mathrm{M} \mathrm{HCl}$ & $30 \mathrm{~mL}$ of $0.01 \mathrm{M} \mathrm{HCl}$ & $0.5-\mathrm{mL}$ fractions of $1 \mathrm{M} \mathrm{HCl}$ & (9) \\
\hline \multicolumn{5}{|c|}{$\begin{array}{l}{ }^{\star} \text { Dow Chemical Co. } \\
{ }^{\dagger} \text { Bio-Rad Laboratories, Inc. } \\
\text { DGA = N,N,N',N'-tetra-n-octyldiglycolamide. }\end{array}$} \\
\hline
\end{tabular}


TABLE 2

${ }^{52} \mathrm{Mn}$ Separation Methods

\begin{tabular}{|c|c|c|c|c|}
\hline Resin & Target dissolution & Target material eluent & 52gMn eluent & Reference \\
\hline Dowex 50 WX8 & $1 \mathrm{~mL}$ of fuming $\mathrm{HCl}$ & $0.1 \mathrm{M} \mathrm{H}_{2} \mathrm{SO}_{4}$ & $\begin{array}{l}0.067 \mathrm{M} \text { ammonium } \\
\text { citrate, } \mathrm{pH} \text { 7.3-7.4 }\end{array}$ & (33) \\
\hline $\mathrm{AG}^{\dagger} 1-\mathrm{X} 8$ & $11.3 \mathrm{M} \mathrm{HCl}$ & $\begin{array}{l}5 \mathrm{~mL} \text { of } 0.1 \mathrm{M} \mathrm{HCl}, 10 \mathrm{~mL} \\
\text { of } \mathrm{H}_{2} \mathrm{O}, 3 \%(\mathrm{v} / \mathrm{v}) 11.3 \mathrm{M} \mathrm{HCl}\end{array}$ & $2 \mathrm{~mL} 0.1 \mathrm{M} \mathrm{HCl}$ & $(29,32,35,36)$ \\
\hline $\mathrm{AG}^{\dagger} 50 \mathrm{~W}-\mathrm{X} 8$ & Diluted $\mathrm{HCl}$ & $0.1 \mathrm{M}$ sulfuric acid & $6 \mathrm{M} \mathrm{HCl}$ & (38) \\
\hline $\begin{array}{l}\mathrm{AG}^{\dagger} 1-\mathrm{X} 8 \text {, organic } \\
\text { extraction }\end{array}$ & $12.1 \mathrm{M} \mathrm{HCl}$ & $\begin{array}{l}\text { Chromium ions remained in } \\
\text { aqueous phase }\end{array}$ & $\begin{array}{l}10 \mathrm{~mL} 0.8 \mathrm{M} \text { trioctylamine in } \\
\text { cyclohexane, organic phase }\end{array}$ & (32) \\
\hline
\end{tabular}

between 6 and $20 \mathrm{MeV}$, illustrating production of ${ }^{52} \mathrm{Mn}$ with low-energy cyclotrons $(29,30,32-34)$.

Several separation methods have been developed for the purification of ${ }^{52 \mathrm{~g}} \mathrm{Mn}$ and are summarized in Table 2 $(35,36)$. Although further optimization of the purification chemistry is required, these purification strategies have enabled the availability of this nuclide for research use.

\section{RADIOCHEMISTRY AND IMAGING OF ${ }^{52} \mathrm{MN}$}

The radiochemistry of manganese has been deemed challenging because manganese and chromium have multiple oxidation states and because $\mathrm{Mn}$ (II) and $\mathrm{Cr}$ (III) behave similarly (32). Recent studies have noted that ${ }^{52 \mathrm{~g}} \mathrm{Mn}$ can be chelated with EDTA, DTPA, and DOTA, with straightforward labeling chemistry similar to radionuclides of scandium previously discussed (36). ${ }^{52 \mathrm{~g}} \mathrm{Mn}$ has been used in several imaging applications. For example, recent studies showed that $\mathrm{Mn}^{2+}$ can enter neurons, and thus, ${ }^{52 \mathrm{~g}} \mathrm{Mn}$ has been studied as a neural imaging agent (37). Because manganese is also used as a contrast agent in manganese-enhanced MRI, MRI tools can benefit from the use of ${ }^{52 \mathrm{~g}} \mathrm{Mn}$ to enhance the understanding of the pharmacokinetics of these agents (38). An excellent example of using ${ }^{52 \mathrm{~g}} \mathrm{Mn}$ for dual PET/ MRI made use of $\mathrm{Mn}^{2+}$ for manganese-enhanced MRI and ${ }^{52 \mathrm{~g}} \mathrm{Mn}$ for PET imaging studies on neural progenitor cells that overexpress divalent metal transporter 1 (32). Researchers found that the effectiveness of cell therapy could be measured using the dual-modality PET/MRI method by applying divalent metal transporter 1 as a reporter gene (32). In another study, the use of ${ }^{52 \mathrm{~g}} \mathrm{Mn}$ coupled with a DOTA antibody conjugate (DOTA-TRC105) for PET imaging of mice bearing 4T1 xenografts was reported (34). That study showed that ${ }^{52 \mathrm{~g} M n}$ can be used as a PET agent for imaging time points of up to $120 \mathrm{~h}$ and resulted in high-quality images as shown in Figure 1. Although DOTA-coupled compounds can be labeled with both ${ }^{52 \mathrm{~g}} \mathrm{Mn}$ and ${ }^{43,44 \mathrm{~g}} \mathrm{Sc}$, the application is important for radionuclide selection, with the former having longer imaging times and the latter being used for the development of true theranostics (28).
Another interesting study showed the uptake of ${ }^{52 \mathrm{~g} M n-}$ $\mathrm{Mn}^{2+}$ in monkeys after nostril administration of the radiotracer (37). Brain uptake in rhesus macaque monkeys was determined over 8 sessions with at least 6 mo between each session. After $7 \mathrm{~d}$, activity was seen in parts of the brain after following the olfactory tract, which demonstrated that ${ }^{52 \mathrm{~g}} \mathrm{Mn}-\mathrm{Mn}^{2+}$ can be used to for neuronal imaging (39). ${ }^{52 \mathrm{~g}} \mathrm{Mn}-\mathrm{Mn}$ (oxinate) ${ }_{2}$ was synthesized and determined to have suitable in vitro stability to study extravasation in vivo when conjugated with a liposomal nanomedicine (40). In another study, which leveraged the biologic properties of $\mathrm{Mn}^{2+}$, ${ }^{52 \mathrm{~g}} \mathrm{Mn}^{2+}-\mathrm{Mn}^{2+}$ was successfully used to image functional $\beta$-cell mass in mice with type 1 and type 2 diabetes (41). Finally, ${ }^{52 \mathrm{~g}} \mathrm{Mn}^{2+}-\mathrm{Mn}^{2+}$ was used to investigate the biodistribution of manganese when administered intravenously or through inhalation (38). That study found most organs to have higher uptake when the dose was administered intravenously, with the highest uptake being in the kidney and liver (38). In summary, the implementation of ${ }^{52 \mathrm{~g}} \mathrm{Mn}$ could provide a new way to image long-circulating compounds and to enhance the results from manganese MRI tools.

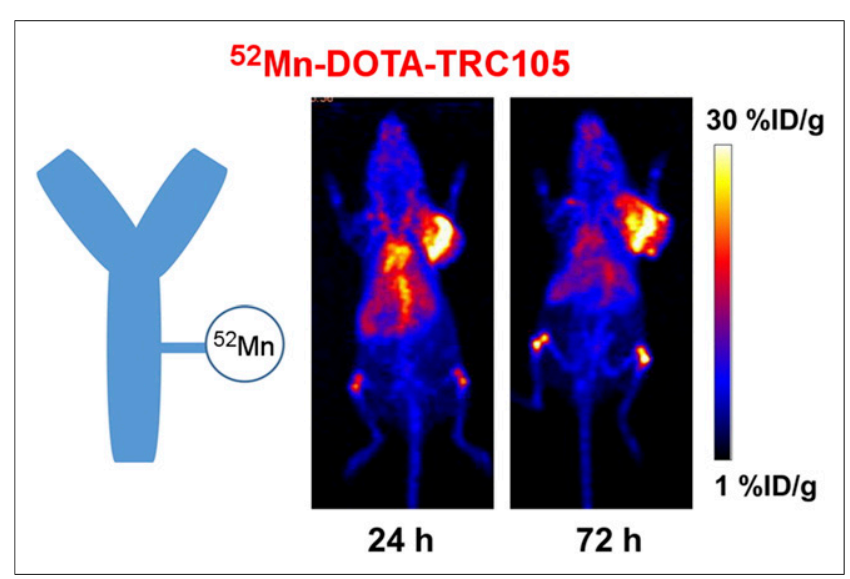

FIGURE 1. Results of ${ }^{52} \mathrm{Mn}$-DOTA-TRC105 injection into 4T1 xenograft tumor-bearing mice. \%ID = percentage injected dose. (Reprinted with permission from (34).)

$$
{ }^{43,44} \mathrm{Sc},{ }^{52} \mathrm{MN}, \text { AND }{ }^{45} \mathrm{TI} \text { - Chaple and Lapi }
$$




\section{PRODUCTION OF ${ }^{45} \mathrm{TI}$}

${ }^{45}$ Ti has many favorable characteristics for PET imaging, including a naturally monoisotopic target material, a halflife of $3.08 \mathrm{~h}$, low maximum positron energy $\left(\mathrm{E}_{\beta+}=439\right.$ $\mathrm{keV})$, and a high positron branching ratio $\left(\beta^{+}=84.8 \%\right)$. Compared with the previous nuclides discussed, ${ }^{45} \mathrm{Ti}$ production may be the most economical. Although not heavily studied to date, recent articles showed the utility of ${ }^{45} \mathrm{Ti}$. ${ }^{45} \mathrm{Ti}$ is produced via proton bombardment of natural scandium foils through the ${ }^{45} \mathrm{Sc}(\mathrm{p}, \mathrm{n})^{45} \mathrm{Ti}$ reaction. Promising results were achieved using 11.8-MeV protons to avoid production of the long-lived ${ }^{44} \mathrm{Ti}$ (42). An excellent review article has described the historical interest and significance of ${ }^{45} \mathrm{Ti}$, as well as some of the most recent advances in its production and separation methods (43). For the purification of ${ }^{45} \mathrm{Ti}$, studies have used hydroxamate resin with reported yields of up to $42 \% \pm 6 \%$, with a separation time of an hour (42). Production yields of $4.6 \pm 0.4 \mathrm{GBq}(20 \mu \mathrm{A}, 11.8 \mathrm{-MeV}$ protons, $1 \mathrm{~h})$ have been reported, compared with previously calculated theoretic yields of $2.165 \mathrm{GBq}(5 \mu \mathrm{A}, 14.5-\mathrm{MeV}$ protons, $1 \mathrm{~h})$ (42,44-46). A novel separation method achieved 93\% \pm 3\% recovery via use of a HypoGel 200 (Rapp Polymere $\mathrm{GmbH}$ ) 1,3-diol resin to retain ${ }^{45} \mathrm{Ti}$ on the column and then subsequently introduced salan followed by dipic in pyridine for radiolabeling on the same column, to produce ${ }^{45} \mathrm{Ti}$-(salan)Ti(dipic) (47). These production parameters indicate that ${ }^{45} \mathrm{Ti}$ can be readily produced in significant quantities using low-cost target material.

\section{RADIOCHEMISTRY AND IMAGING OF ${ }^{45} \mathrm{TI}$}

Radiochemistry with ${ }^{45} \mathrm{Ti}$, which exists in the +3 and +4 oxidation states, is challenging because of the potential oxidation of $\mathrm{Ti}$ to $\mathrm{TiO}_{2}$, its instability in an aqueous environment, and the challenge of finding stable titanium chelators (47). Researchers illustrated that ${ }^{45} \mathrm{Ti}$ could be used to radiolabel mesoporous silica nanoparticles using a chelatorfree radiolabeling technique (42). In another study using an on-column radiolabeling technique, the radiolabeled antitumor agent ${ }^{45} \mathrm{Ti}$-(salan)Ti(dipic) was applied for PET/CT imaging and biodistribution studies and showed rapid clearance from blood and liver, whereas the uptake in the tumor remained constant for $400 \mathrm{~min}$ (47). Previous studies showed that ${ }^{45} \mathrm{Ti}$ could be used to radiolabel apotransferrin, which forms a complex that remains intact in vivo, demonstrating transport of ${ }^{45} \mathrm{Ti}$ to tumors for $24 \mathrm{~h}$ after injection (48). ${ }^{45} \mathrm{Ti}$ can yield high-resolution images as illustrated with recent phantom imaging studies in our group. Figure 2 shows a miniature Derenzo phantom imaged with $3.7 \mathrm{MBq}$ of ${ }^{45} \mathrm{Ti}$ on the small-animal PET scanner at the University of Alabama at Birmingham. When isotopes with moderate half-lives are compared, ${ }^{45} \mathrm{Ti}$ and ${ }^{43,44 \mathrm{~g}} \mathrm{Sc}$ are comparable; however, the straightforward production may make ${ }^{45} \mathrm{Ti}$ more appealing as a diagnostic radionuclide if chemistry challenges can be overcome.

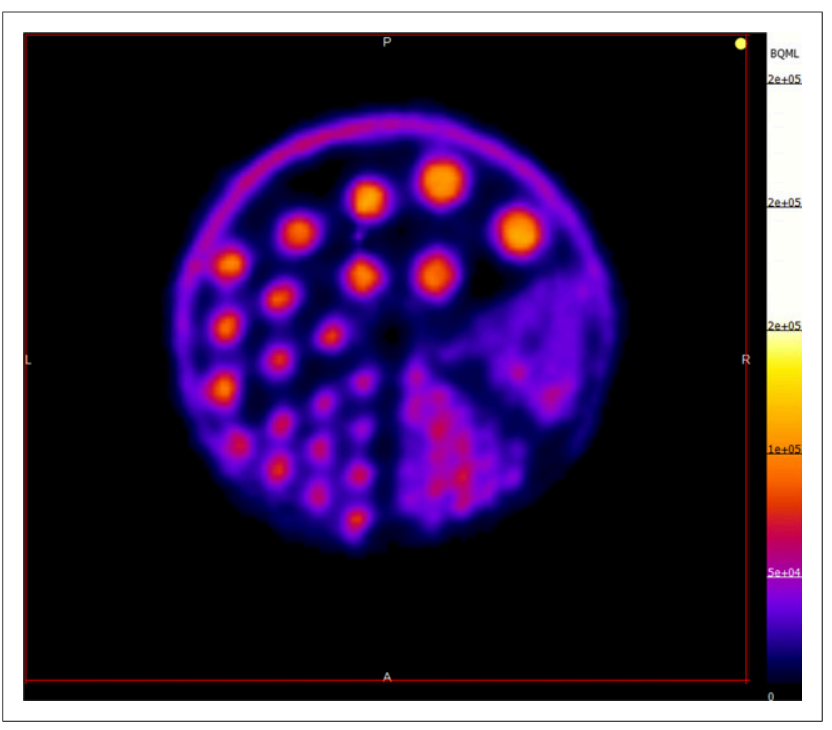

FIGURE 2. Miniature Derenzo phantom image (3.7 MBq of ${ }^{45} \mathrm{Ti}$; image taken after 60-min scan time).

\section{CONCLUSION}

The field of nuclear imaging is growing rapidly, with many recent advancements being made in the area of radioisotope development and implementation. Each of these isotopes possesses unique properties. The characteristics of ${ }^{43,44 \mathrm{~g}, \mathrm{~m}} \mathrm{Sc}$ may allow for implementation as theranostic agents when combined with ${ }^{47} \mathrm{Sc}$. The long half-life of ${ }^{52 \mathrm{~g}} \mathrm{Mn}$ is promising for longer imaging studies and could be used for the development of PET/MRI agents. ${ }^{45} \mathrm{Ti}$ is an interesting isotope that has much to offer, with its favorable half-life and potential ease of production. With additional development, ${ }^{43,44 \mathrm{~g}, \mathrm{~m}} \mathrm{Sc},{ }^{52 \mathrm{~g}} \mathrm{Mn}$, and ${ }^{45} \mathrm{Ti}$, may prove to be useful additions to the PET isotope toolbox.

\section{DISCLOSURE}

No potential conflict of interest relevant to this article was reported.

\section{REFERENCES}

1. Rogosnitzky M, Branch S. Gadolinium-based contrast agent toxicity: a review of known and proposed mechanisms. Biometals. 2016;29:365-376.

2. Müller C, Domnanich KA, Umbricht CA, van der Meulen NP. Scandium and terbium radionuclides for radiotheranostics: current state of development towards clinical application. Br J Radiol. June 15, 2018 [Epub ahead of print].

3. Singh B, Chen J. Nuclear data sheets for A = 43. Nucl Data Sheets. 2015;126: $1-150$.

4. Alliot C, Kerdjoudj R, Michel N, Haddad F, Huclier-Markai S. Cyclotron production of high purity ${ }^{44 \mathrm{~m}, 44} \mathrm{Sc}$ with deuterons from ${ }^{44} \mathrm{CaCO}_{3}$ targets. Nucl Med Biol. 2015;42:524-529.

5. Szkliniarz K, Sitarz M, Walczak R, et al. Production of medical Sc radioisotopes with an alpha particle beam. Appl Radiat Isot. 2016;118:182-189.

6. Minegishi K, Nagatsu K, Fukada M, Suzuki H, Ohya T, Zhang M-R. Production of scandium-43 and -47 from a powdery calcium oxide target via the ${ }^{\text {nat } / 44} \mathrm{Ca}(\alpha, \mathrm{x})$ channel. Appl Radiat Isot. 2016;116:8-12.

7. Duchemin C, Guertin A, Haddad F, Michel N, Metivier V. Production of scandium- $44 \mathrm{~m}$ and scandium- $44 \mathrm{~g}$ with deuterons on calcium-44: cross section measurements and production yield calculations. Phys Med Biol. 2015;60:68476864. 
8. Radchenko V, Meyer CAL, Engle JW, et al. Separation of ${ }^{44} \mathrm{Ti}$ from proton irradiated scandium by using solid-phase extraction chromatography and design of ${ }^{44} \mathrm{Ti} /{ }^{44} \mathrm{Sc}$ generator system. 2016;1477:39-46.

9. Walczak R, Krajewski S, Szkliniarz K, et al. Cyclotron production of ${ }^{43} \mathrm{Sc}$ for PET imaging. EJNMMI Phys. 2015;2:33.

10. Carzaniga TS, Auger M, Braccini S, et al. Measurement of ${ }^{43} \mathrm{Sc}$ and ${ }^{44} \mathrm{Sc}$ production cross-section with an $18 \mathrm{MeV}$ medical PET cyclotron. Appl Radiat Isot. 2017;129:96-102.

11. Hernandez R, Valdovinos HF, Yang Y, et al. ${ }^{44} \mathrm{Sc}$ : an attractive isotope for peptide-based PET imaging. Mol Pharm. 2014;11:2954-2961.

12. Eppard E, de la Fuente A, Mohr N, et al. Labeling of DOTA-conjugated HPMAbased polymers with trivalent metallic radionuclides for molecular imaging. EJNMMI Res. 2018;8:16.

13. Müller C, Bunka M, Haller S, et al. Promising prospects for ${ }^{44} \mathrm{Sc}-/{ }^{47} \mathrm{Sc}$-based theragnostics: application of ${ }^{47} \mathrm{Sc}$ for radionuclide tumor therapy in mice. $\mathrm{J} \mathrm{Nucl}$ Med. 2014;55:1658-1664.

14. Valdovinos HF, Hernandez R, Barnhart TE, Graves S, Cai W, Nickles RJ. Separation of cyclotron-produced ${ }^{44} \mathrm{Sc}$ from a natural calcium target using a dipentyl pentylphosphonate functionalized extraction resin. Appl Radiat Isot. 2015;95c:23-29.

15. Chakravarty R, Goel S, Valdovinos HF, et al. Matching the decay half-life with the biological half-life: immunoPET imaging with ${ }^{44} \mathrm{Sc}$-labeled cetuximab Fab fragment. Bioconjug Chem. 2014;25:2197-2204.

16. Hoehr C, Oehlke E, Benard F, et al. ${ }^{44 \mathrm{~g}} \mathrm{Sc}$ production using a water target on a 13MeV cyclotron. Nucl Med Biol. 2014;41:401-406.

17. Synowiecki MA, Perk LR, Nijsen JFW. Production of novel diagnostic radionuclides in small medical cyclotrons. EJNMMI Radiopharm Chem. 2018;3:3.

18. Domnanich KA, Eichler R, Müller C, et al. Production and separation of ${ }^{43} \mathrm{Sc}$ for radiopharmaceutical purposes. EJNMMI Radiopharm Chem. 2017;2:14.

19. Eppard E, De La Fuente A, Benešová M, et al. Clinical translation and first inhuman use of $\left[{ }^{44} \mathrm{Sc}\right] \mathrm{Sc}-\mathrm{PSMA}-617$ for PET imaging of metastasized castrateresistant prostate cancer. Theranostics. 2017;7:4359-4369.

20. Severin GW, Engle JW, Valdovinos HF, Barnhart TE, Nickles RJ. Cyclotron produced ${ }^{44 \mathrm{~g} S c}$ from natural calcium. Appl Radiat Isot. 2012;70:1526-1530.

21. Alliot C, Audouin N, Barbet J, et al. Is there an interest to use deuteron beams to produce non-conventional radionuclides? Front Med (Lausanne). 2015;2:31.

22. Duchemin C, Guertin A, Haddad F, Michel N, Métivier V. Corrigendum: production of scandium- $44 \mathrm{~m}$ and scandium- $44 \mathrm{~g}$ with deuterons on calcium44 - cross section measurements and production yield calculations (2015 Phys. Med. Biol. 60 6847-64). Phys Med Biol. 2016;61:3637.

23. Roesch F. Scandium-44: benefits of a long-lived PET radionuclide available from the ${ }^{44} \mathrm{Ti} /{ }^{44}$ Sc generator system. Curr Radiopharm. 2012;5:187-201.

24. van der Meulen NP, Bunka M, Domnanich KA, et al. Cyclotron production of ${ }^{44}$ Sc: from bench to bedside. Nucl Med Biol. 2015;42:745-751.

25. Müller C, Bunka M, Reber J, et al. Promises of cyclotron-produced ${ }^{44} \mathrm{Sc}$ as a diagnostic match for trivalent $\beta^{-}$-emitters: in vitro and in vivo study of a ${ }^{44} \mathrm{Sc}-$ DOTA-folate conjugate. J Nucl Med. 2013;54:2168-2174.

26. Pérez-Malo M, Szabó G, Eppard E, et al. Improved efficacy of synthesizing *MIIIlabeled DOTA complexes in binary mixtures of water and organic solvents. a combined radio- and physicochemical study. Inorg Chem. 2018;57:6107-6117.

27. Nagy G, Denes N, Kis A, et al. Preclinical evaluation of melanocortin-1 receptor (MC1-R) specific ${ }^{68} \mathrm{Ga}$ - and ${ }^{44} \mathrm{Sc}-$ labeled DOTA-NAPamide in melanoma imaging. Eur J Pharm Sci. 2017;106:336-344.

28. Domnanich KA, Müller C, Farkas R, et al. ${ }^{44} \mathrm{Sc}$ for labeling of DOTA- and NODAGA-functionalized peptides: preclinical in vitro and in vivo investigations. EJNMMI Radiopharm Chem. 2016;1:8.
29. Fonslet J, Tietze S, Jensen AI, Graves SA, Severin GW. Optimized procedures for manganese-52: production, separation and radiolabeling. Appl Radiat Isot. 2017; $121: 38-43$.

30. Wooten AL, Lewis BC, Lapi SE. Cross-sections for $(\mathrm{p}, \mathrm{x})$ reactions on natural

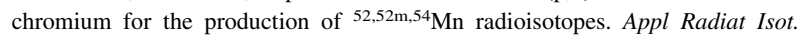
2015;96:154-161.

31. Kakavand T, Mirzaii M, Eslami M, Valizadeh S. Cyclotron production of ${ }^{52} \mathrm{Mn}$ and Monte Carlo benchmarking. J Radioanalytical Nucl Chem. 2015;304:669674.

32. Brunnquell C, Graves S, Hernandez R, et al. ${ }^{52} \mathrm{Mn}$ production for PET/MRI tracking of human stem cells expressing divalent metal transporter 1 (DMT1). Theranostics 2015;5:227-239.

33. Buchholz M, Spahn I, Scholten B, Coenen HH. Cross-section measurements for the formation of manganese-52 and its isolation with a non-hazardous eluent. Radiochimica Acta. 2013;101:491-499.

34. Graves SA, Hernandez R, Fonslet J, et al. Novel preparation methods of ${ }^{52} \mathrm{Mn}$ for immunoPET imaging. Bioconjug Chem. 2015;26:2118-2124.

35. Topping GJ, Schaffer P, Hoehr C, Ruth TJ, Sossi V. Manganese-52 positron emission tomography tracer characterization and initial results in phantoms and in vivo. Med Phys. 2013;40:042502.

36. Jensen AI, Severin GW, Hansen AE, et al. Remote-loading of liposomes with manganese-52 and in vivo evaluation of the stabilities of ${ }^{52} \mathrm{Mn}$-DOTA and ${ }^{64} \mathrm{Cu}-$ DOTA using radiolabelled liposomes and PET imaging. J Control Release. 2018;269: 100-109.

37. Saar G, Millo CM, Szajek LP, Bacon J, Herscovitch P, Koretsky AP. Anatomy, functionality, and neuronal connectivity with manganese radiotracers for positron emission tomography. Mol Imaging Biol. 2018;20:562-574.

38. Wooten AL, Aweda TA, Lewis BC, Gross RB, Lapi SE. Biodistribution and PET imaging of pharmacokinetics of manganese in mice using manganese-52. PLoS One. 2017; 12:e174351.

39. Napieczynska H, Severin GW, Fonslet J, et al. Imaging neuronal pathways with ${ }^{52} \mathrm{Mn}$ PET: toxicity evaluation in rats. Neuroimage. 2017;158:112-125.

40. Gawne P, Man F, Fonslet J, et al. Manganese-52: applications in cell radiolabelling and liposomal nanomedicine PET imaging using oxine (8hydroxyquinoline) as an ionophore. Dalton Trans. 2018;17:9283-9293.

41. Hernandez R, Graves SA, Gregg T, et al. Radiomanganese PET detects changes in functional beta-cell mass in mouse models of diabetes. Diabetes. 2017;66: 2163-2174.

42. Chen F, Valdovinos HF, Hernandez R, Goel S, Barnhart TE, Cai W. Intrinsic radiolabeling of titanium-45 using mesoporous silica nanoparticles. Acta Pharmacol Sin. 2017;38:907-913.

43. Costa P, Metello L, Alves F, Duarte Naia M. Cyclotron production of unconventional radionuclides for PET imaging: the example of titanium-45 and its applications. Instruments. 2018;2:8.

44. Gagnon K, Severin GW, Barnhart TE, Engle JW, Valdovinos HF, Nickles RJ. ${ }^{45} \mathrm{Ti}$ extraction using hydroxamate resin [abstract]. AIP Conf Proc. 2012;1509:211.

45. Holland JP, Sheh Y, Lewis JS. Standardized methods for the production of high specific-activity zirconium-89. Nucl Med Biol. 2009;36:729-739.

46. Vāvere AL, Laforest R, Welch MJ. Production, processing and small animal PET imaging of titanium-45. Nucl Med Biol. 2005;32:117-122.

47. Severin GW, Nielsen CH, Jensen AI, Fonslet J, Kjær A, Zhuravlev F. Bringing radiotracing to titanium-based antineoplastics: solid phase radiosynthesis, PET and ex vivo evaluation of antitumor agent [ $\left.{ }^{45} \mathrm{Ti}\right]($ salan)Ti(dipic). J Med Chem. 2015;58:7591-7595.

48. Vavere AL, Welch MJ. Preparation, biodistribution, and small animal PET of ${ }^{45}$ Ti-transferrin. J Nucl Med. 2005;46:683-690. 